\title{
CONTENT ANALYSIS OF FACULTY WEB SITES
}

\author{
Olivera Iskrenovic-Momcilovic \\ Faculty of Education, University of Novi Sad, Serbia \\ Podgoricka 4, 25000 Sombor, Serbia \\ e-mail: oljkaisk@yahoo.com
}

\begin{abstract}
The content published on faculty web pages is an important source of information about the work of the faculty, which affects the performance of all student activities. It is therefore important to know what information is relevant to the student, as well as to what extent the content is published on the web site of the faculty in accordance with the needs of the student. Starting from the above, the subject of research of this paper is the content of the web sites of faculties of the University of Novi Sad. The main aim of the research is to determine whether there is and to what extent a certain content is present on the faculty web pages, as well as on the basis of the conducted research to provide suggestions for the improvement of web information in higher education.
\end{abstract}

Keywords: content analysis, faculty, information, students, web sites.

\section{INTRODUCTION}

In a world dominated by the Internet, communication is reduced to short messages, and people's immediate contact is replaced with messages on the screen. Sociologists believe that any communication is better than any. The higher education area also uses the Internet. It is necessary to provide fast and reliable information exchange as well as unlimited contact between teachers, current and future students [1].

The potential of the Internet is used successfully by companies engaged in the placement of products and services, but their use is also desirable for the promotion of higher education institutions [2,3]. The Internet allows data transfer at a high speed and thus creates a bridge between the sender and the recipient. In this way, the largest number of higher education institutions opens up the possibility for advertising through web sites [1, 4].

The Internet is an important source of information for any sphere of creativity. Information related to faculties is one of the most popular content areas on the Internet $[5,6]$. Of great importance is the knowledge of the students' interest because it offers a clear view of the faculty web site. It is necessary to know how and where students look for information, how much information from certain sources is important to them, and on the basis of which factors they make decision on enrollment, choice of literature and way of learning. It's not easy at all, because student behavior is complex.

Regardless of all the problems, the application of the Internet for information has become an imperative in higher education [7, 8]. The advantages of the Internet, such as availability, convenience, interactive communication and time limitations have affected the Internet today to become an irreplaceable tool for informing a modern student who is rich in time, but poor in knowledge. In doing so, web sites, which form the basis of information via the Internet, must be created in a way that will facilitate the search and indicate the user for longer retention [9].

The Internet provides online information retrieval, characterized by a relatively low price, customized information, ease of comparing information, interactivity, virtual community formation and 24-hour accessibility [10]. In order for online search of information to be

\section{IRTIIE Vol. 7, No. 2, 2019 ISSN 1314-8788 (print), ISSN 1314-8796 (online), doi: 10.15547/artte.2019.02.010}




\section{ARTTIE $Y$}

Ipplied Resseirlohes in Teechnics, Technologies and Bducation

Journal of the Faculty of Technics and Technologies, Trakia University https://sites.google.com/a/trakia-uni.bg/artte/

successful, three conditions must be met: ease of access to information, ease of use and reliability [11]. Web sites should be intuitive, interactive, and compatible with other search engines, and in line with user needs to enable them to find what they are searching for [12]. Students expect faculty web sites to be informative, interactive and attractive. They must be designed to respond to all the needs of students [13-15]. Students are most in need of information about exams, lectures and exercises, then enrolment, directions and graders.

\section{METHODOLOGY}

The subject of the research is the content of faculties of the faculty, which belong to the University of Novi Sad. The University of Novi Sad has a total of 14 faculties: Faculty of Philosophy, Faculty of Agriculture, Faculty of Law, Faculty of Law, Faculty of Economics, Faculty of Technical Sciences, Faculty of Medicine, Faculty of Science, Academy of Arts, Faculty of Civil Engineering, Mihajlo Pupin Technical Faculty, Faculty sport and physical education, the Faculty of Education and the Faculty of Teacher Education in the Hungarian language.

The method of content analysis was applied in the research. According to Hsieh and Shannon content analysis is defined as a method of research intended for subjective interpretation of the content of textual data through the systemic classification of coding processes and the identification of items or samples. 19 According to Kolbe and Burnet, content analysis is a technique for an objective, quantitative and generalized description of the obvious content of symbolic communication.

All information within the content of the web pages is divided into eight categories, and then these categories are divided into elements. Each element was evaluated individually by marks from 1 to 5 . For each web site of the faculty, the average grade for a particular category was calculated. In the end, the overall average rating of all facets of the faculty is calculated. The categories and elements of the faculty web site are:

1. Homepage: Logo of faculty, Full name of faculty, Main menu, Search, Language selection, Faculty images, Current news, Auxiliary menu, Faculty address, Page title;

2. General information about faculty: History, Study programs, Teaching timetable, Academic calendar, Legal acts, Price list, Admission, Information on activities, Accreditation, Departments;

3. Employees: Teachers, Teaching assistants, Non-teaching staff, Workplace description, Biographies, Images, Choice in academic title;

4. Contact: Address, Telephone, Fax, E-mail, Location, Bank account, Contact form;

5. Social Networks: Facebook, Twitter, YouTube, Instagram, Content sharing, Cooperation with networks, User suggestions;

6. Multimedia: Colors, Images Animations, Gallery, Pop-up windows, Banners, Customizable appearance;

7. Faculty services: Students services, Library, Passed exams, Online exam registration, News archive, Scholarships, Publications, Useful hyperlinks, Faculty structure, Student parliament, Teaching materials, International cooperation;

8. Functionality: Multilingualism, Quick search, Site map, Correct hyperlinks, Page loading speed, Functional menu, Download, Update date, Mobile view, Print, Adequate age title, Home page button. 


\section{RESULTS AND DISCUSSION}

The evaluation of web site elements is done by the categories listed in the previous section. Each of the elements of the category received a score of 1 to 5 and calculated the average score by elements and categories.

Table 1 shows that the average score for the Home page is 4.24. Faculty logo (5), Faculty full name of faculty (5) and Main menu (5) are represented on all faculties of the faculty. At least there is Faculty address (3.07), Faculty images (3.71) and Assistant menu (3.79).

Based on Table 1, it can be concluded that the average score for the category General Information about faculty is noted to be 4.19. A smaller number of faculties provided information about History (3) and Price List (3.21) on their web sites. Information on Legal Acts (4.86), Study Programs (4.79) and Teaching timetable (4.64) can be found most.

Table 1. Home page faculty and general information about faculty

\begin{tabular}{|l|c|l|c|}
\hline \multicolumn{1}{|c|}{ Homo page } & Average score & General information about faculty & Average score \\
\hline Faculty logo & 5,00 & History & 3,00 \\
\hline Faculty full name & 5,00 & Study programs & 4,79 \\
\hline Main menu & 5,00 & Teaching timetable & 4,64 \\
\hline Search & 4,14 & Academic calendar & 4,14 \\
\hline Language selection & 4,00 & Legal acts & 4,86 \\
\hline Faculty images & 3,71 & Price list & 3,21 \\
\hline Current news & 4,14 & Addmisssion & 4,29 \\
\hline Assistant menu & 3,79 & Information on activities & 4,21 \\
\hline Faculty address & 3,07 & Acreditation & 4,36 \\
\hline Page title & 4,50 & Departments & 4,36 \\
\hline \multicolumn{1}{|c|}{$\Sigma$} & 4,24 & & 4,19 \\
\hline
\end{tabular}

The average score for the category Employees is 3.74 according to Table 2. The most information can be found in the form of the list of Teachers (4.64) and Teaching Assistants (4.64), as well as the necessary information for Choice in academic title (4.43). The least information on the faculty website can be obtained about Non-teaching staff (2.36).

Table 2. Employees and contact

\begin{tabular}{|l|c|l|c|}
\hline \multicolumn{1}{|c|}{ Employees } & Average score & \multicolumn{1}{c|}{ Contact } & Average score \\
\hline Teachers & 4,64 & Address & 4,79 \\
\hline Teaching assistants & 4,64 & Telephone & 5,00 \\
\hline Non-teaching staff & 2,36 & Fax & 5,00 \\
\hline Workplace description & 3,14 & E-mail & 5,00 \\
\hline Biographies & 3.50 & Location & 4,50 \\
\hline Images & 3,50 & Bank account & 3.79 \\
\hline Choice in academic title & 4,43 & Contact form & 3,15 \\
\hline \multicolumn{1}{|c|}{$\Sigma$} & 3,64 & $\Sigma$ & 4,64 \\
\hline
\end{tabular}




\section{ARTTE $Y$}

Ipplied Resseirlohes in Teechnics, Technologies and Bducation

Journal of the Faculty of Technics and Technologies, Trakia University https://sites.google.com/a/trakia-uni.bg/artte/

The category Contact is well represented on all web pages, which is also indicated by the average score of 4.64 in Table 2. It is possible to find information about Telephone $(5,00)$, Fax $(5,00)$ and E-mail $(5,00)$ on all web pages, but it is surprising that not all pages represented Address (4.79). However, it was most difficult to find information about Bank account (3.79).

The smallest content, which is located on all faculty websites, is related to the category Social Networks (2.48). From Table 3, it is noticed that the average score is 2.48. Most faculty websites have a link to their Facebook page (4.57). The least represented content is a part that allows users to suggest Suggestions for page improvement (1.29), then a link to Instagram (1.57) and Twiter (2.14) page.

As for the category Multimedia, the average score is 3.48 , based on Table 3 . On most web sites, there is the option of Customizable appearance (3.93). The same average grade is for Images $(3,93)$, which shows that all faculties web sites do not use their own images of the buildings or students themselves. The faculties web sites have the smallest dynamics, ie Animations $(2,93)$ and Pop-up windows $(3,14)$.

Table 3. Social networks and multimedia

\begin{tabular}{|l|c|l|c|}
\hline \multicolumn{1}{|c|}{ Social networks } & Average score & \multicolumn{1}{c|}{ Multimedia } & Average score \\
\hline Facebook & 4,57 & Colors & 3,43 \\
\hline Twitter & 2,14 & Images & 3,93 \\
\hline YouTube & 2,64 & Animations & 2,93 \\
\hline Instagram & 1,57 & Gallery & 3,43 \\
\hline Content sharing & 2,64 & Pop-up windows & 3,14 \\
\hline Cooperation with networks & 2,50 & Banners & 3.57 \\
\hline User suggestions & 1,29 & Customizable appearance & 3,93 \\
\hline$\Sigma$ & 2,48 & \multicolumn{1}{c}{$\Sigma$} & 3.48 \\
\hline
\end{tabular}

Based on Table 4, for the category Faculty Services, it is noted that the average score is 3.64. It is possible to find information about Passed exams (5.00) on all faculties web pages, but we can also conclude that not all web sites have the possibility of On-line exam registration (4.43) and Publications (4.29), issued by faculty. In this category, Teaching materials (2.86) are the least available, which can be downloaded from the web site to help students learn, as well as the News archive (2.86) and information on Scholarships (2.93).

The category Functionality has average score 3.87, which can be seen from Table 4 . On all faculties of the website, Download (5.00) functioned well and there was no delay or inability to download certain content. In addition, most web sites have Correct hyperlinks (4.79), and Page loading speed (4.71) is satisfactory. The least represented functionality is Site Map (1.79) and besides Print web site (2.14). 


\section{ART'TlE $Y$}

Ipplied Reseirl'ches in Technics, Technologies and Bduration

Journal of the Faculty of Technics and Technologies, Trakia University https://sites.google.com/a/trakia-uni.bg/artte/

Table 4. Faculty services and functionality

\begin{tabular}{|l|c|l|c|}
\hline \multicolumn{1}{|c|}{ Faculty services } & Average score & \multicolumn{1}{c|}{ Functionality } & Average score \\
\hline Students services & 3,07 & Multilingualism & 3,36 \\
\hline Library & 3,79 & Quick search & 3,86 \\
\hline Passed exams & 5,00 & Site map & 1,89 \\
\hline On-line exam registration & 4,43 & Correct hyperlinks & 4,79 \\
\hline News aechive & 2,86 & Page loading speed & 4,71 \\
\hline Scholarships & 2,93 & Functional menu & 4,14 \\
\hline Publications & 4,29 & Download & 5,00 \\
\hline Useful hyperlinks & 4,00 & Update date & 3,36 \\
\hline Faculty structure & 3,14 & Mobile view & 4,36 \\
\hline Students parliament & 3,07 & Print & 2,14 \\
\hline Teaching materials & 2,86 & Adequate page title & 4,43 \\
\hline International cooperation & 4,29 & Home page button & 4,50 \\
\hline \multicolumn{2}{|c|}{$\Sigma$} & 3,64 & \multicolumn{2}{c}{$\mathbf{2}$} & 3,87 \\
\hline
\end{tabular}

After analyzing the obtained results, it is concluded that the category Contact $(4,64)$ has the highest average score and the category Social Media $(2,48)$ the smallest average score. The average score of the total content of faculties web pages is 3.87. It shows that the total content of the web pages of most faculties is very good, but also that it can still be improved and improved.

Based on the average score by categories, as well as the total content score, it is noted that there are some disadvantages or insufficient representation of certain content on the faculty web pages. These disadvantages can be eliminated by improving the content with the following suggestions:

1. In the category Home page, it is necessary to add information about the faculty's Address, as well as the faculty Images. Adding Language selectiom and Search to some web sites.

2. In the category General information about faculty it is necessary to add more quality information about History and easy to find the Price list. The general complaint is that on most websites, general data is more difficult to find, so it is necessary to correct this.

3. The category Employees has least informations about Non-teaching staff, so it is necessary to add this information in order to get a better picture of the faculty's work. It is also necessary to add information on which subjects a particular teacher is teaching, which can help new students better choose the faculty.

4. The most content is in the category Contact, the only disadvantage being that the Bank account should be easily accesible how to found it quickly.

5. The smallest content is in the category Social Networks, so it's necessary to add links to social networks, such as Twitter, Instagram and YouTube. In addition, all web sites do not have the ability to show users their Suggestions, which is a big disadvantage.

6. In the category Multimedia, you need to add Animations and Pop-up windows to improve the display dynamics and to make the content on the web pages "live". Websites should have as good a gallery as possible in order to better reflect the work of faculties for future students.

7. In the category Faculty services, it is advisable to add as many Teaching materials as possible so that students can easily learning. Student-related information, such as Scholarships and Student parliament, are not found on most websites, which is a major IRTIIE Vol. 7, No. 2, 2019 ISSN 1314-8788 (print), ISSN 1314-8796 (online), doi: 10.15547/artte.2019.02.010 


\section{ARTTE $Y^{2}$}

Ipplied Resseirlohes in Teechnics, Technologies and Bducation

Journal of the Faculty of Technics and Technologies, Trakia University https://sites.google.com/a/trakia-uni.bg/artte/

disadvantage because students, those who access this information, are the ones who are in the mood.

8. For the category Functionality, you need to add the Site Map to a large number of websites to facilitate the movement through the entire website. In addition, it is necessary to highlight Update TIme of web pages so that users can see how much information is new. Another major flaw is Multilingualism. Most faculty websites have a choice between Serbian or English, and this choice does not display all the content in another language. It is necessary to correct this option, as well as to add the possibility of choosing Latin or Cyrillic, because of students from abroad, who would like to study at just one of the faculties in their own country.

Taking into account all categories, it can be suggested in general that faculties work on better design, appearance, colors and display of information on web pages, in order to leave as many positive impressions as possible to the users, whether teachers or current or future students.

Finally, in the end, a comparative analysis of the content published on the web pages was carried out according to the scientific field of work of the faculty. The faculties of the University of Novi Sad are grouped in the following way:

1. Social-Humanities (DH): Faculty of Philosophy, Faculty of Law, Faculty of Economics, Academy of Arts, Faculty of Education and Teacher Training College in Hungarian language.

2. Science and mathematics (PM): Faculty of Agriculture, Faculty of Science and Faculty of Sport and Physical Education.

3. Technical-technological sciences (TT): Faculty of Technology, Faculty of Technical Sciences, Faculty of Civil Engineering and Technical Faculty "Mihajlo Pupin".

4. Medical Sciences (M): Faculty of Medicine.

Table 5 shows average grades for content categories on faculty web pages, grouped according to the scientific mood of work. It is noted that the content from the category Contact is the most represented on the faculty web site with an average score of 4.59, followed by the Home page (4.21) and the category General information about the faculty (4.04). The lowest content is represented in the category Social Networks with the lowest average score of 2.26 .

If we compare the content of the web site according to the field of work of the faculty, it can be seen from Table 5 that their average grades are about the same, which leads to the conclusion that the content on different websites is roughly equal. A slightly higher average grade of 3.86, from other faculties, received web pages belonging to technical and technological sciences, which implies that these web sites possess more information.

Table 5. Comparative analysis of the contents of web pages according to the scientific field of work of the faculty

\begin{tabular}{|l|c|c|c|c|c|}
\hline \multirow{2}{*}{ Category } & \multicolumn{3}{c|}{ Scientific field of work } & \multirow{2}{*}{ Sum } \\
\cline { 2 - 5 } & DH & PM & TT & M & \\
\hline Home page & 4,25 & 4,30 & 4,30 & 4,00 & 4,21 \\
\hline General information about faculty & 4,15 & 3,78 & 3,95 & 4,27 & 4,04 \\
\hline Employees & 3,59 & 3,90 & 4,00 & 3,14 & 3,66 \\
\hline Contact & 4,50 & 4,60 & 4,85 & 4,40 & 4,59 \\
\hline Social networks & 2,54 & 2,33 & 2,75 & 1,42 & 2,26 \\
\hline Multimedia & 3,4 & 3,42 & 3,64 & 3,85 & 3,58 \\
\hline Faculty services & 3,75 & 3,64 & 3,51 & 3,50 & 3,60 \\
\hline Functionality & 3,8 & 3,86 & 3,89 & 4,17 & 3,93 \\
\hline Total & 3,75 & 3,73 & 3,86 & 3,59 & 3,73 \\
\hline
\end{tabular}

IRTIIE Vol. 7, No. 2, 2019 ISSN 1314-8788 (print), ISSN 1314-8796 (online), doi: 10.15547/artte.2019.02.010 


\section{CONCLUSION}

The Internet is developing and progressing at a high speed, so today it is possible to find millions of websites. Some of them are dynamic, some static, some are customized to all users, and some are trying to attract a certain group of people. What is common to all websites is content, which provides an overview of a wide variety of information. Web sites as Internet information providers must satisfy users' expectations in order to attract their attention right now and encourage further search. The existence of quality content, that is, current and reliable information, is a prerequisite for successful information.

The research has shown that various information is available on the Faculty's website. Most contact information is represented, and the smallest information is related to social networks. It should be emphasized that all faculties regardless of the field of work have the content of a similar web site and that almost the same information is published on them. Based on the research done on the current state of the faculty web site, recommendations for improving information in higher education can be given.

Content on faculty web pages should be well organized and logically organized, easily accessible and quality. Special attention should be given to future students, because their information can be useful for enrolling the desired faculty. Likewise, a quality website will make it easier for current students, as well as faculty members, to find the necessary information. Website faculties can be an ideal resource for teachers, current and future students.

\section{REFERENCES}

[1] Manzoor, M., Hussain, W., Ahmed, A. \& Iqbal, M. J. (2012). The importance of higher education web sites and its usability. International Journal of Basic and Applied Sciences, Vol. 1, No. 2, 2012, pp. 150-163.

[2] Ford, W. (2011). Evaluating The effectiveness of college web sites for prospective students. Journal of College Admission, Summer, 2011, pp. 26-31.

[3] Hackett, S. \& Parmanto, B. (2005). A longitudinal evaluation of accessibility: higher education web sites. Internet Research, Vol. 15, No.3, 2005, pp. 281-294.

[4] Xenos, M., Dermitzioti, E. \& Pierrakeas, C. (2004). Assessing the quality of web-sites used in higher open distance education courses. Education, Communication and Information Journal, Vol. 4, No. 2/3, 2004. p. 237.

[5] Petrovic, D. (2016). Use of internet resources and IT tools and characteristics of higher education institutions. Megatrend Review, Vol. 13, No. 1, 2016, pp. 293-304.

[6] Young, H. \& Hyunjoo, I. (2012). Role of web site design quality in satisfaction and word of mouth generation. Journal of Service Management, Vol. 23, No. 1, 2012, p. 79.

[7] Katirci, H. (2016). Comparison of the content of web sites of higher education institutions providing for sports management education: The case of Turkish and English universities. Educational Research and Reviews, Vol. 11, No. 8, 2016, pp. 562-572.

[8] Patral, M. R. \& Dash, A. R. (2017). Accessibility analysis of some Indian educational web portals. International Journal of Computer Science, Engineering and Applications, Vol. 7, No. 3/4, 2017, pp. 41-45.

[9] Silva, V. (2012). Web site quality evaluation in higher education institutions. Procedia Technology. Vol. 5, 2012, pp. 73-282.

[10] Wang, F., Head, M. \& Arthur, N. (2002). E-tailing: an analysis of web impacts on the retail market. Journal of Business Strategies, Vol. 19, No. 1, 2002, pp. 3.-93

[11] Kozak, M. \& Decrop, A. (2009). Handbook of Tourist Behavior: theory and practice. Taylor \& Francis, New York, 2009.

IRIIIE Vol. 7, No. 2, 2019 ISSN 1314-8788 (print), ISSN 1314-8796 (online), doi: 10.15547/artte.2019.02.010 
[12] Aladwani, A. M. \& Palvia, P. C. (2002). Developing and validating an instrument for measuring user-perceived web quality. Information and Management, Vol. 39, 2002, p. 467.

[13] Akkan, E. \& Bozyigit, S. (2014). The importance of having a web sites on marketing of educational services: Investigation of State Universities in Turkey. Çağ Üniversitesi Sosyal Bilimler Dergisi, vol. 11, no. 1, 2014, pp. 84-99.

[14] Iwaarden, J. V., Van der Wiele, T., Ball, L. \& Millen, R. (2004). Perceptions about the quality of web sites: a survey amongst students at Northeastern University and Erasmus University. Information and Management, vol. 41, 2004, p. 947.

[15] Jager, J., \& Plooy, T. (2010). Information sources used to select a higher education institution: Evidence from South African students. Business Education and Accreditation, vol. 2, no. 1, 2010, pp. 61-76. 